\title{
The Issue of Palestine and Globalisation: From a Clash of Civilisations Perspective
}

Mohamad Zaidin Mohamad, Ahmad Fauzi Hasan, Ahmad Zahid Salleh, Mohd Faiz Hakimi Mat Idris, Sofyuddin Yusof, Abdillah Hisham Abdul Wahab, Yulisman Nazim

To Link this Article: http://dx.doi.org/10.6007/IJARBSS/v11-i7/10414

DOI:10.6007/IJARBSS/v11-i7/10414

Received: 15 May 2021, Revised: 18 June 2021, Accepted: 30 June 2021

Published Online: 06 July 2021

In-Text Citation: (Mohamad et al., 2021)

To Cite this Article: Mohamad, M. Z., Hasan, A. F., Salleh, A. Z., Idris, M. F. H. M., Yusof, S., Wahab, A. H. A., \& Nazim, Y. (2021). The Issue of Palestine and Globalisation: From a Clash of Civilisations Perspective. International Journal of Academic Research in Business and Social Sciences, 11(7), 47-54.

Copyright: (c) 2021 The Author(s)

Published by Human Resource Management Academic Research Society (www.hrmars.com) This article is published under the Creative Commons Attribution (CC BY 4.0) license. Anyone may reproduce, distribute, translate and create derivative works of this article (for both commercial and non-commercial purposes), subject to full attribution to the original publication and authors. The full terms of this license may be seen

at: http://creativecommons.org/licences/by/4.0/legalcode

Vol. 11, No. 7, 2021, Pg. 47 - 54

Full Terms \& Conditions of access and use can be found at http://hrmars.com/index.php/pages/detail/publication-ethics 


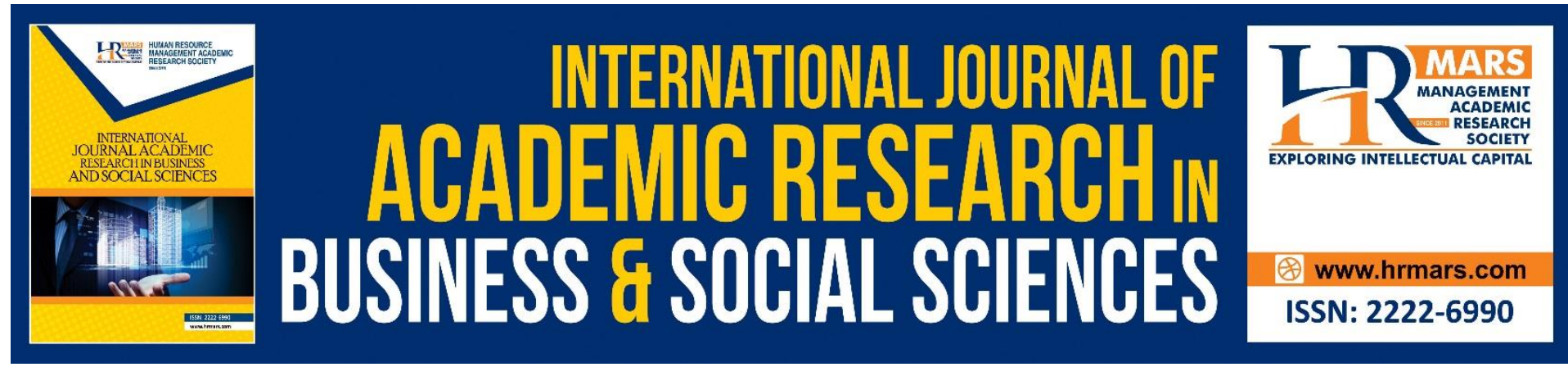

\title{
The Issue of Palestine and Globalisation: From a Clash of Civilisations Perspective
}

\author{
Mohamad Zaidin Mohamad ${ }^{1}$, Ahmad Fauzi Hasan ${ }^{1}$, Ahmad \\ Zahid Salleh ${ }^{1}$, Mohd Faiz Hakimi Mat Idris ${ }^{1}$, Sofyuddin Yusof ${ }^{1}$, \\ Abdillah Hisham Abdul Wahab ${ }^{1}$, Yulisman Nazim² \\ ${ }^{1}$ Faculty of Islamic Contemporary Studies, UniSZA, Malaysia, ${ }^{2}$ Faculty of Social and Political \\ Science, Universitas Teuku Umar, Indonesia \\ Email: mzaidin@unisza.edu.my
}

\begin{abstract}
The clash of civilisations concept is an antonym to the dialogue of civilisations concept. This concept is frequently highlighted on the academic and political stage when discussions linger around global discontent. Palestine and globalisation were chosen for discussion in order to discover the significance of these issues and its relations to the clash of civilisations. This qualitative study adopted the content analysis design based on relevant sources. Findings indicate that values related to the clash of civilisations are crucial to the issue of Palestine and globalisation. Hence, the world should pay serious attention to both these issues as all interested parties sincerely advocate the successful application of the dialogue of civilisations concept.
\end{abstract}

\section{Introduction}

The clash of civilisations is an international relations theory popularised by Samuel Huntington in 1993. This theory has caused heated debates in the political as well as academic worlds. In addition, the Cold War between America and Russia ended not too long ago, while the conflict between America and Iran concerning Iran's nuclear weapons has reached its climax. The Palestine and globalisation issue, which was chosen for discussion from a clash of civilisation perspective, is an interesting topic because both have similarities from the aspect of impact, which leads to conflict, and a clash of civilisations, specifically between the Islamic world and the West.

\section{The Issue of Palestine}

The creation of Israel is the result of the Jewish political movement, which refers to the Zionist who aimed to solve the issue of the Jews that peaked at the end of the $19^{\text {th }}$ century due to a rise in large scale Anti-Semitic movements in Europe. The successful creation of Israel in Palestine in 1948 had caused a new problem, basically the usurpation of Palestinian rights (Fawaz, 1997). Among some of the clear-cut weaknesses of Huntington's clash of civilisations concept was the act of ignoring America's foreign policy as the cause of the conflict, mainly the policy on the Palestine issue (West Asia). This factor was totally ignored although it was 
the main issue that caused the outrage among Muslims towards America, which led some to believe that the Israeli-Palestine conflict was the centre of the clash. A stand such as this was not only the belief of Muslims, but the West themselves also admitted to this fact. The United Nations has also failed to play its role in solving this humanitarian conflict (George, 2009).

The 9/11 tragedy has a strong connection to the Palestine issue. However, this issue has been purposely kept silent in order to cover up the error in American policy and safeguard American-Israeli relations. During a House of Representatives sitting, Cynthia McKinney, the representative from Georgia, tried to suggest that America re-evaluate the Palestinian issue. Unfortunately, she was vehemently attacked by several representatives who claimed that she was being Anti-Semantic and supported terrorists (Abrahamian, 2010).

This situation actually reflects the overwhelming influence of Jews on the White House administration. Israel is one country that commands a special status because it is the recipient of the single largest amount of financial assistance from America. For example, in 2003 it received direct assistance amounting to USD140 billion. Israel also receives approximately USD3 billion as direct foreign aid every year, which is approximately $1 / 5$ of America's foreign aid. From the per capita aspect, America contributes approximately USD500 to each Jew every year (Mearsheimer \& Walt, 2006).

Besides that, America also maintains interest in Israel's security and military. Financial assistance amounting to USD3 billion has been extended for developing Israel's weapon's system, such as building of the Levi aircraft, Blackhawk helicopter and the F-16 fighter jet. Israel has also gained access to America's CIA. At the same time, America has closed one eye to Israel's building and ownership of nuclear weapons (Mearsheimer \& Walt, 2006). America's close diplomatic ties with Israel is evident. Since 1982, America has exercised its veto power on 32 occasions to censor criticism by the UN Security Council on Israel. The veto has also been used to block efforts by the Arab Block to enter Israel's nuclear silo and facilities under the supervision of the IAEA. America has also saved Israel during times of war and sided with Israel in each and every peace mission. Moreover, one American official involved in the Camp David Accords asserted that, "we act ... as Israels" attorneys".

According to Mearsheimer, America's strong support for Israel reflects the influence exerted by Israel's lobbyist so much so that America's support for Israel's interests far overshadows America's own as well as its people's interests (Chomsky, 1999). Matthew A. Baum proved this point through an analysis carried out to determine the level of trust the American people had in America's role in international relations between 1958-2008. Findings show that the level of trust increased to $75 \%$ when the country was under the leadership of George W. Bush. The war against Iraq and terrorism was at the top of the list of problems faced by America at that time (Baum \& Groeling, 2010).

The religious factor also helped the Jews influence America. This is evident in the role played by a group of Christian-Jews, which was an off-shoot of the Protestant movement that was influenced by Jewish teachings, which led them to believe that Christian teachings originated from Jewish teachings. In America, the Jews are known to control almost all the Christians. This situation allows the Jews to portray an image that Islam is the enemy of the Christians. 
The clash of civilisations created by Huntington is a form of propaganda to instigate enmity between Christians and Muslims (Al-Yaziji, 2004).

Although the presumption is that the Torah (Old Testament) compliments the Bible (New Testament) and it can corrupt original Christian teachings; however, this group was willing to carry it out due to its fanatical attitude. According to Christian beliefs, actual Christian teachings are similar to that of Islam, whereby it advocates equality and harmony, while the teachings of the Torah aim to safeguard the interests of the Jews even though it could lead to enmity and tyranny. Thus, by accepting the Torah as the sacred scripture of the Christians, the Christians need to accept the Jews as the "Chosen People" (al-Sha'b al-Mukhtar). They also have to support all the desires and commands of the Torah demanded of the Jews although it is clearly against the teachings of Christianity. The fanaticism of this ChristianJewish group had led to this group being called the "Christian-Zionist" group. It wields immense influence in America, especially in New York (Al-Yaziji, 2004). It is not surprising that this sort of influence in the West, especially in America, has caused Islam to be viewed with extreme prejudice. In addition, the Jews own some of the biggest broadcasting and advertising companies that allows them to manipulate the news and facts related to the Islamic world.

The Jews have used all the instruments, either in the form of religion, politics, economy or the mass media, to safeguard their interests and in all actuality, they have succeeded. The pro-Israeli attitude shown by American leaders further supports the statements Jimmy Carter once made.

"The American-Israeli relationship - as advocated by seven previous leaders of America - is more than a special relationship. Moreover, it is based on sentiments, morality, religion and the American people's beliefs. We, together, believe in the Torah", (Hammad, 1409H)

Although the world knows that the nation of Israel was created out of the land of Palestine in a conniving and deceitful manner, America still recognises Israel as a rightful and legal entity because it is in line with the teaching of the Torah. Ronald Reagan once said,

"I always see the Zionist movement as basically the planning of the Jews. With the creation of Israel, they will return to administer it themselves, in their historical homeland, to realise their dream since thousands of years ago", (Hammad, 1409H)

Clinton clearly stated that America is obliged to help the Jews to move the Jewish immigrants to Palestine (Hammad, 1409H). This situation became more apparent when Donald Trump became the President of America. On 6 December 2017, he declared Jerusalem (Baitul Maqdis) as the capital of Israel and moved the American embassy from Tel Aviv to Jerusalem (Eriksson, 2018). Meanwhile, Joe Biden, who became the President of America in 2020, continued to support Israel although the Israelis' actions surpass basic humanitarian standards when they purposely target civilians and their homes as well as public buildings, such as hospitals, schools and banks, when launching attacks on Gaza. Biden asserted that America would continue to extend financial assistance to Israel although they receive assistance from various other parties (https://www.theguardian.com). 
Following the discussion above, it can be summarised that the clash of civilisations concept has indeed numerous advantages to the Jews. The disparaging relationship between the Islamic world and the West is a welcoming circumstance for the Jews. This is because there are parties that try to associate Huntington's personal life with the Jews and the clash of civilisations concept with Jewish interests. In brief, the Jews use their strong influence in the West, especially in America, to foster their interest in Palestine (Abu-Rudeneh, 1972).

\section{The Issue of Globalisation}

The issue of globalisation is a global topic that comprises various dimensions. From a historical perspective, globalisation emerged as a world economic development concept based on an open market. In other words, it is a continuation of Western capitalist policy (Benerjee \& Linstead, 2001). Hence, to associate globalisation solely with the economic aspect is inaccurate because globalisation is significantly related to other aspects, including politics, culture, religion, knowledge and demographics. This is not unusual because the dimensions of human life are very wide and they influence one another. Thus, globalisation obtains its "global" status after considering its terms, discussions and effects (Nazari, 2007).

There are numerous definitions of the word 'globalisation'. The various definitions are based on diverse aspects as seen or valuated by an individual. According to Jan Scholte, the Joint Director for the Centre for the Study of Globalisation and Regionalisation in the University of Warwick (UK), "there are various elements affiliated with the definition of globalisation that portray positive or negative aspects generally inherent in the word" (Infed Encyclopaedia, 2012).

The question is why are there views that associate globalisation with the clash of civilisations. Among the books related to globalisation from an Islamic perspective are al-Muslimun wa alAkhar: Hiwar la Sidam (essay by Ali al-Qurashi), Sidam al-Hadarat: Hatmiyyah Qadariyyah am Lawthah Bashariyyah (essay by Hasan al-Bash), and Sira' al-Umam bayn al-'Awlamah wa alDimaqratiyyah (Ascad al-Samahrani). This is as if there are some clear negative elements existing in globalisation, just as in the clash of civilisations. These negative elements have some similarities and a strong relationship with the clash of civilisations. The most apparent negative element in globalisation is the Westernisation, or more accurately, the Americanisation.

The author realises the main reason why Westernisation has taken a global dimension, so much so that globalisation has received incredible resistance. First, the element of Westernisation has an apparent effect on the world compared to other effects, and second, the element of Westernisation poses a big threat to the two core properties of national identity that should be defended at all costs, namely religion and culture (Nefeily, 2009). From a psychological viewpoint, values of self-identity act as a strong motivational force for an ethnic group to rise, reject and defend all forms of threats on their normal life (Salzman, 2008).

Among some of the similarities that exist between globalisation and the clash of civilisations are: 
a. Safeguarding the interest of one party, which is America. Globalisation is an agenda to continue the hegemony of the West, which uses every opportunity available to achieve this aim. The world's largest institution, namely the UN and especially its Security Council, has been dragged into this quagmire by yielding to America's wishes (George, 2009). Globalisation is an attack on the world's culture, society, economy and politics, which threatens traditional values and national identity (Al-Samahrani, 2000). America's stand as the main player in globalisation has put the world in doubt; although various aspirations and good tides related to the advantages of globalisation have been mentioned. This doubtfulness has its basis. America's attack on Iraq, which in the process ignored the role of the UN, proved that America wanted to singlehandedly control the world and monopolise its riches. Globalisation has clearly succeeded in turning America into a dominant power at the global level in various aspects, such as the economy, culture, communication and politics (Hui \& Mun, 2007).

b. Oppression of the weak. The tide of globalisation is a global phenomenon that is almost impossible to de-escalate or slacken (Steger, 2005). Third-world countries are forced to become involved in globalisation with the hope of enhancing the economy and developing the country. In reality, globalisation leads to an increasing gap between the rich and poor countries. Globalisation is a new form of global colonisation that centres on capitalist policies, which is portrayed fallaciously as conveying democratic values and practices to the third world. Clearly, globalisation has changed the internal structure of a country based according to the mould of another country (globalisation player) (Sklair, 1995). Michael Goulding, an economist with the World Bank, stated in an interview with Global Vision, "Globalization is, by its nature, a carrot and stick process, its economics, politics and human rights. You encourage countries to participate in the global economy and that forces them to change internal behaviours and standards".

Thus, due to this injustice, globalisation increases the feeling of disappointment, anger and despair among the third world society. This scenario could continue and eventually spiral out of control leading to unconceivable actions and violence (AbuNimah, 2008).

c. The uniqueness of culture is threatened. Globalisation is an attack on the world and coerces the world to accept the culture of the 'main player' in globalisation, which is the American culture. Globalisation is an Americanisation concept that marginalises the humanitarian cause. Hence, it is not surprising that resistance against this new colonisation concept is expressed by most world societies, regardless of whether it is the Eastern or Western societies.

Demonstrations that erupt are symbols of dissatisfaction and anger expressed by societies around the world that understand and have experienced themselves how their national culture is threatened and eroded by the tides of globalisation. Notably, protests not only occur in the form of demonstrations but also in the form of violence (Salzman, 2008). Assimilation of the American culture on a global scale is facilitated by the role played by the media, corporate advertisements and the entertainment industry. The American-style living culture, which is represented through products or brands, such as Nike, fashion, music, Disney products, film, Coca-Cola, McDonalds, ESPN, CNN and lots more that can be found in every corner of this world. Internet, for example, has brought enormous changes to the world's societies by increasing the crime rate and other social ills. Issues involving pornography, 
gambling, drug abuse and theft are phenomena that have caused grave concern all over the world (Eitzen \& Zinn, 2006).

d. Global stability is threatened. The greatest effect and impact of globalisation is conflict and war. The 9/11 tragedy fully portrays an example of how globalisation causes dissatisfaction among parties who feel that they, as well as their race, country and religion, are threatened (Knight \& Mousseau, 2003). This reality is supported by several studies, one being "Globalization, Multiculturalism and Other Fictions: Colonialism for the New Millennium" by Subhabrata \& Linstead, which found that globalisation lays the groundwork for injustice, corruption and violence (Salzman, 2008). Globalisation is also seen as a war strategy. Thomas Friedman, a columnist and advocate of globalisation, had written in the New York Times Magazine, published in March 1999, that "Globalization is not just a trend, not just a phenomenon, not just an economic fad. It is the international system that has replaced the cold-war system" (Eitzen \& Zinn, 2006).

The threat of globalisation is supported by various factors, such as military strength, economy, technology, diplomatic ties, culture and language, which are extremely dangerous to the stability of this world. America is not only seen as a superpower but has rather become a hyperpower.

Hence, globalisation from its historical and characteristic aspects, clearly indicates a significant relationship with the clash of civilisations concept. Therefore, it is not surprising if certain parties introduce globalisation the main agenda in discussions related to the clash of civilisations.

\section{Conclusion}

Based on the discussions above, undoubtedly the issue of Palestine and globalisation are closely related with the clash of civilisations concept. Egoism and the compulsion to accept others' culture are negative values that lead to rejection and resistance by the weak. In brief, as long as values associated with the clash of civilisations are not countered with serious assimilation and empowerment of values associated with civilisational dialogue in the context of the society, this world is far from embracing any success.

\section{References}

Abrahamian, E. (2003). The US media, Huntington and September 11. Third World Quarterly. 24(3): 529-544.

Nefeily, A. (2009). It is 'Dialogue' not 'Clash'. Kaherah: Dar An-Nashr Liljami'at.

Abu Rudeneh, O. (1972). The Jewish factor in US politics. Journal of Palestine Studies. 1(4): 92-107.

Baum, M., \& Groeling, T. (2010). Reality asserts itself: public opinion on Iraq and the elasticity of reality. International Organization 64, Summer: 443-79.

Benerjee, S. B., \& Linstead, S. (2001). Globalization, multiculturalism and other fictions: colonialism for the new millennium. Organization. 8(4): 683-722.

Chomsky, N. (1999). Fateful Triangle: The United States, Israel and the Palestinian, Cambridge: South End Press.

Eitzen, D. S., \& Zinn, M. B. (2006). Globalization The Transformation of Social Worlds. United Kingdom: Thomson Wadsworth. 
Eriksson, J. (2018). Master of None: Trump, Jerusalem and the Prospects of Israeli-Palestinian Peace. Middle East Policy. 25(2): 51-63.

Fawaz A. G. (1997). Islam and Muslims in the mind of America: Influences on the making of U.S. policy. Journal of Palestine Studies. XXVI(2): 68-80.

George, M. (2009). Reforming the United Nations Organisation: philosophical and practical underpinnings. Global Change, Peace \& Security. 21(2): 257-267.

Hammad, A. B. (1409H). Athar al-inhiraf al-'aqdi wa al-fikr 'ind al-Yahud 'ala al-fikr al-sahyuni Hassan, A. N. (2008). Globalization and the International Order, In Globalization in the 21st Century: How Interconnected is the World? The Emirates Center For Strategic Studies and Research.

Hui, L. K., \& Mun, H. W. (2007). Globalisasi, Media dan Budaya. Kuala Lumpur: Dewan Bahasa dan Pustaka.

Infed Encyclopedia. (2012). Definition of Globalization, http://www.infed.org/biblio/defining_globalization.html, [19 April 2012].

Knight, C. \& Mousseau, M. (2003). The Sources of Terrorism. International Security. 28(2): 192-198.

Sklair, L. (1995). Sociology of the Global System. Baltimore, MD: Johns Hopkins University Press.

Mearsheimer, J., \& Walt, S. M. (2006). The Israel lobby and U.S. foreign policy, Middle East Policy.13( 3): 1-59.

Ismail, M. N. (2007). The Globalisation Debate: A Case of Barking the Wrong Tree. Kuala Lumpur: UM Press.

Salzman, M. B. (2008). Globalization, religious fundamentalism and the need for meaning. International Journal of Intercultural Relations. 32: 318-327.

Al-Samahrani, A. (2000). Sira' al-Umam bayn al-'Awlamah wa al-Dimaqratiyyah. Beirut: Dar alNafa'is.

Steger, M. B. (2005). Ideologies of Globalization. Journal of Political Ideologies. 10(1): 11-30.

Al-Yaziji, I. (2004). al-Masihiyyah al-Mutawahhidah fi Khidmat al-Sahyuniyyah al-'Alamiyyah. Damshik: al-Dar al-Wataniyyah al-Jadidah li al-Nashr wa al-Tawzi' 